\title{
Immunoscreening of Alpha-Tocopherol in Breast, Prostate Cancers and in Gestational Choriocarcinoma Tissues
}

\author{
Henriette Poaty ${ }^{1,2^{*}}$, Franck Arnaud Moukobolo Kinsangou1, Alexis F. Bolenga Liboko1,3, \\ Judith Nsonde Malanda1,3, Michel Geffard ${ }^{4}$
}

${ }^{1}$ Faculty of Health Sciences, Marien Ngouabi University, Brazzaville, Congo

${ }^{2}$ National Research Institute on Health Sciences (IRSSA), Brazzaville, Congo

${ }^{3}$ Oncology Service, Teaching hospital, Brazzaville, Congo

${ }^{4}$ Institut pour le Développement de la Recherche en Pathologie Humaine et Thérapeutique, Talence, France

Email: ^henriettepoaty@gmail.com

How to cite this paper: Poaty, H., Kinsangou, F.A.M., Bolenga Liboko, A.F., Malanda, J.N. and Geffard, M. (2021) Immunoscreening of Alpha-Tocopherol in Breast, Prostate Cancers and in Gestational Choriocarcinoma Tissues. CellBio, 10, 11-21.

https://doi.org/10.4236/cellbio.2021.102002

Received: February 23, 2021

Accepted: April 13, 2021

Published: April 16, 2021

Copyright $\odot 2021$ by author(s) and Scientific Research Publishing Inc. This work is licensed under the Creative Commons Attribution International License (CC BY 4.0).

http://creativecommons.org/licenses/by/4.0/

\begin{abstract}
Background: Many literature reviews report vitamin E supplementation as a benefit chemopreventive and adjuvant therapy in breast and prostate cancers. We investigated in the present work, alpha-tocopherol $(\alpha-\mathrm{T})$ expression (the current active form of vitamin E) from tissues of Congolese patients neither smokers nor alcohol drinkers and without intake antioxidant vitamins supplement. Methods: $\alpha$-T was analysed in one normal placenta of nine weeks of gestation and in nineteen cancerous tissues, including seven breast cancers, six prostate cancers, and six gestational choriocarcinomas. The study was performed by immunohistochemistry method after diagnosis confirmation by histological analysis. Results: $\alpha$-T staining in membrane cells and collagen fibers presented a moderate expression in healthy sections of tissues (positive control), but the labelling was strong in breast, prostate adenocarcinomas, and in choriocarcinomas. Conclusion: Tumors immunohistochemistry of $\alpha$-tocopherol in breast, prostate cancers and in choriocarcinoma show elevated immunostaining suggesting a probable oncogenic effect of the micronutrient.
\end{abstract}

\section{Keywords}

Vitamin E, Alpha-Tocopherol Immunohistochemistry, Breast Cancer, Prostate Cancer, Choriocarcinoma

\section{Introduction}

Preventing vitamins consumption, or the use of adjuvant vitamin therapy after a 
cancer diagnosis is common [1]. It concerns $36 \%$ to $87 \%$ of United States breast cancers [2]. Vitamin $\mathrm{E}$ is the micronutrient mostly consumed (45.6\% of cases), as an anticancer and antitoxicity agent [2] [3]. Vitamin $\mathrm{E}$ is a liposoluble molecule, the metabolism of which is comparable to lipid [3] [4] [5]. It contains two natural members: tocopherols (T) and tocotrienols divisible in four variants: alpha $(\alpha)$, beta $(\beta)$, gamma $(\gamma)$ and delta $(\delta)$, and all forms don't have the same biological activities [6] [7]. $\alpha$-tocopherol $(\alpha$-T) variant is different from others forms by the presence of three methyl groupments $\left(\mathrm{CH}_{3}\right)$ (Figure 1). It is the compound form preferentially used in organism, with high biological function as antioxidant activity [4] [8] [9].

Vitamin $\mathrm{E}$ is localized in many normal tissues such as: placenta, liver, brain, heart, kidney (GRCh38/hg 2013). The dietary vitamin supplement is an important subject, because it concerns all malignancies, particularly lung, breast and prostate cancers which are worldwide public health problems.

Indeed, breast cancer is the most common cancer in women worldwide with incidence approximately $20 \%$ of all cancers in European Union [10]. In Congo Brazzaville, it is the first cancer among women. It accounts for $35.8 \%$ of all cancers, between 20 - 75 years old age (Congo cancer registry 2014) [11].

Lung cancer is the most diagnosed cancer in men worldwide $(21 \%$ of all malignancies in China for example) and the leading cause of death [12]. It is followed by the prostate cancer with incidence of $15 \%$ of all malignances among men [13]. But in Congo, because of the low prevalence of smokers (compare to industrialized countries), prostate cancer is the first cancer in males with an incidence of about $37.7 \%$ especially between 55 - 75 years of age (Congo cancer registry 2014) [11].

In those two progressive cancers with high incidence and possibility to be curable, vitamin E supplementation is currently prescribed in chemoprevention or in adjuvant therapy after diagnosis. However, beneficial effects are controversial and are still unclear [1] [2]. Vitamin E supplement is indexed by some authors as a potential factor of cancer risk. It would increase recurrence and mortality of breast and prostate cancer patients [2] [14] [15] [16].

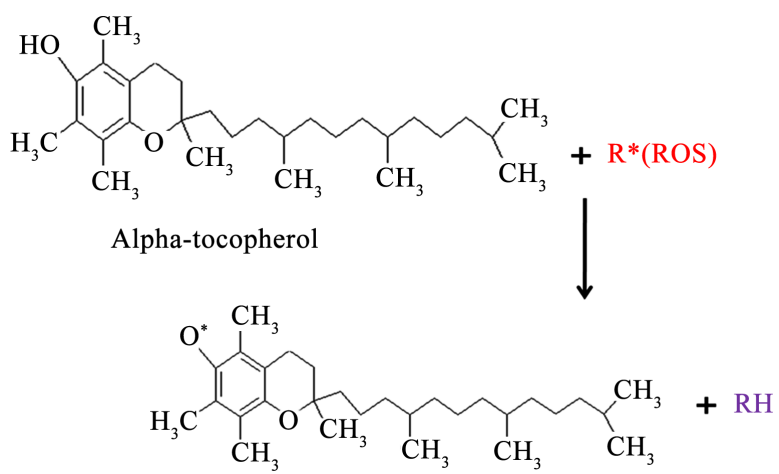

Figure 1. Free radicals scavenging by Alpha-tocopherol. $\alpha$-T has a power to interrupt the autocatalytic chain $\left(\mathrm{R}^{\star}\right)$ by the transfer of the single electron from phenol to free radicals $\mathrm{R}^{\star}$ which become stable molecules (Amanda, 2011). 
Objectives of this study were to examine directly expression of the most active form of vitamin $\mathrm{E}(\alpha$ - $\mathrm{T})$ in choriocarcinoma, breast and prostate cancer tissues sections before chemotherapy.

There are many works on breast and prostate cancers, but, the originality of this work is to have been carried out on Congolese patients.

\section{Materials and Methods}

\subsection{Materials}

We disposed of twenty tissues in paraffin-embedded including: one normal human placenta of nine weeks age, used as an external positive control. Internal positive control was realized in area of healthy tissues and negative control on tissues sections without antibody. Cancer tissues were seven breasts, six prostates and six gestational choriocarcinomas (Table 1 ). The primary tumors were obtained in the first months following diagnosis from Congolese patients neither smokers nor alcohol drinkers and without intake antioxidant vitamins supplement. The work used primary antibody anti $\alpha$-T from host clone rabbit polyclonal. Manufacturer was GEMAC SA (Saint Jean d'Illac, France).

\subsection{Methods}

The transversal study conducted in IRSSA (Brazzaville) was performed by IHC method [17] after histological analysis. The study requires the Medical Congo ethics commission approval number 048/MRSIT/IRSSA/CERSSA.

Histological analysis. The tumoral tissues were fixed in formalin to $10 \%$ and embedded in paraffin blocks, sectioned at 3 microns thickness. The method was realized according standard histological protocol Haematoxylin-Eosin coloration. Histopathologic review confirmed diagnosis of all neoplams.

Table 1. Alpha-tocopherol IHC results.

\begin{tabular}{|c|c|}
\hline Tissues $(n=20)$ & Immunostaining \\
\hline Normal placenta 9 weeks $(n=1)$ & $\begin{array}{l}(++) \text { Moderate labelling of } \\
\text { microvillosities, cytoplasmic membrane in STB, } \\
\text { CTB of villi, mesenchym cells, vascular endothe- } \\
\text { lium cells, leukocytes } \\
\text { and collagen fibers. }\end{array}$ \\
\hline $\begin{array}{c}\text { Breast adenocarcinoma }(\mathrm{n}=7) \\
11 \mathrm{H} 982 \mathrm{~A}, 12 \mathrm{H} 104 \mathrm{~B}, 12 \mathrm{H} 1396, \\
12 \mathrm{H} 1429 \mathrm{~B}, 12 \mathrm{H} 1463 \mathrm{~A}, 12 \mathrm{H} 8641,12 \mathrm{H} 504\end{array}$ & $\begin{array}{l}(+++) \text { High staining of cytoplasmic membrane } \\
\text { of cancerous cells in the proliferating lobule. } \\
(+++) \text { In conjunctive tissue: cytoplasmic } \\
\text { membrane in adipocyte cells, lymphoid stroma, } \\
\text { pseudo capsule, and of collagen fibers. }\end{array}$ \\
\hline $\begin{array}{l}\text { Prostate adenocarcinoma }(\mathrm{n}=6) \\
15 \mathrm{H} 429,15 \mathrm{H} 11,15 \mathrm{H} 46,15 \mathrm{H} 235,15 \mathrm{H} 48,15 \mathrm{H} 499\end{array}$ & $\begin{array}{l}(+++) \text { strong staining of cytoplasmic membrane } \\
\text { in tiny and irregular cancerous glands. } \\
(+++) \text { High staining of smooth muscle fibers } \\
\text { in the prostate's stroma. }\end{array}$ \\
\hline $\begin{array}{c}\text { Gestational choriocarcinoma }(\mathrm{n}=6) \\
\text { M176, M181, M281, M282, M283, 04H449 }\end{array}$ & $\begin{array}{l}(+++) \text { Diffuse labelling of cytoplasmic } \\
\text { membrane cells in STB and CTB. }\end{array}$ \\
\hline
\end{tabular}

Abbreviations: STB, syncytiotrophoblast; CTB, cytotrophoblast. 
Immunohistochemestry. The method was performed with Novolink Polymer Detection System kit (RE7140-K, Novocastra). Primary antibody was diluted to 1:200. Briefly, protocol was as followed: The blocks were sectioned at 3 microns, deparaffinized and rehydrated using xylene and absolute alcohol. The tissue sections underwent in water bath antigen retrieval $10 \mathrm{mM}$ citrate buffer, $\mathrm{pH} 9.0$ (Thermo Scientific, AP-9003-500) at $96^{\circ} \mathrm{C}$ for $45 \mathrm{~min}$. Endogenous peroxidase activity was blocked by antiperoxidase (RE7101) and nonspecific binding was blocked by protein blockers (RE7102). The slides were washed with PBS 1X bath (14200-067, GIBCO). They were incubated $30 \mathrm{~min}$ at room temperature with primary antibody against $\alpha$-T, in humidified airtight chamber, followed by post primary block (RE7111) and novolink polymer (RE7112) for 30 min each other. Visualization of immune complex was performed with diaminobenzidine (RE710) and light counterstaining with Harris haematoxylin (purple nuclear staining). Visualization and photos were realized on Leica optic microscope, using software Leica LAS EZ. $\alpha$-T staining (in brown), was specified as followed: strong expression (+++; $>50 \%$ of cells), moderate expression ( $++; 25 \%$ to $50 \%$ of cells), weakly expression $(+;<25 \%$ of cells) and $(-)$ no labelling [17].

\section{Results}

The results for IHC on all tissues analysed are summarized in Table 1.

\subsection{Breast Cancer}

IHC showed: 1) in healthy section of tissue: a moderate staining in collagen fibers in conjunctive tissue, while reactivity was weak in cytoplasmic membrane of acini, mammary ducts, and in conjunctival stroma cells (Figure 2(a)); 2) in breast adenocarcinoma zone, $\alpha$-T exhibited strong labelling of cytoplasmic membranous cells of the proliferating lobule (containing pseudo acinar formations of cancerous cells, disorganized in honeycomb). It was also strong in lymphoid stroma, pseudo capsule, collagen fibers of conjunctive tissue (Figure 2(b)) and in the adipose tissue (Figure 2(c)).

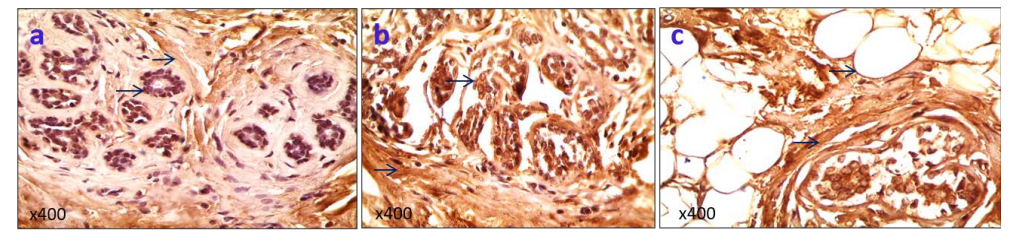

Figure 2. IHC Alpha-tocopherol and breast cancer (12H1396). (a) Healthy section of tumor tissue $\times 40$. Moderate staining $(++)$ of collagen fibers brown colored (up arrow) of conjunctive tissue, constituting a fibrous capsule around the lobule. Moderate expression $(++)$ of cytoplasmic membrane of acini (down arrow), mammary ducts and stromal cells. (b) Cancerous zone (breast adenocarcinoma) $\times 40$. Strong staining $(+++)$ of cytoplasmic membrane cells (up arrow) in the proliferating lobule (containing pseudo acinar formations of cancerous cells, disorganized in honeycomb). It is also strong in lymphoid stroma, pseudo capsule and of collagen fibers (down arrow) of conjunctive tissue. (c) Adipose tissue $\times 40$. Strong staining $(+++)$ of cytoplasmic membrane (up arrow) of adipocyte cells surrounding a cancerous lobe (down arrow). 


\subsection{Prostate Cancer}

IHC presented: 1) in healthy section of tissue, a weakly expression of cytoplasmic membrane in large prostate gland (cystic, pseudo laminated with pseudo papillae), conjunctive tissue and smooth muscle fibers (Figure 3(a)); 2) in prostate adenocarcinoma zone, immunostaining was mostly intense in smooth muscle fibers of the prostatic stroma. Immunostaining was also stronger in cytoplasmic membrane of tiny and irregular cancerous glands none festooned (Figure $3(\mathrm{~b}))$.

\subsection{Gestational Choriocarcinoma}

The normal placenta exhibited a moderate staining of cytoplasmic membrane in STB and CTB cells, mesenchyme and vascular endothelium cells (Figure 4(a)). However, it was mostly strong in mesenchyme collagen fibers.

In choriocarcinomas, staining was stronger and concerned all cytoplasmic membrane cells (Figure 4(b)). All results concerning the tissues including choriocarcinoma are reported in Table 1.

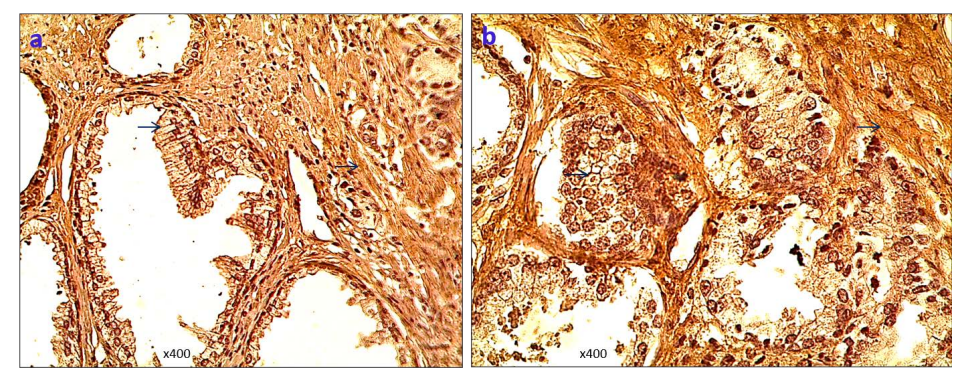

Figure 3. IHC Alpha tocopherol and prostate cancer (15H235). (a) Healthy section of tumor tissue $\times 40$. Moderate staining $(++)$ of cytoplasmic membrane cells (first arrow) of: large prostate gland (cystic, pseudo laminated with pseudo papillae), conjunctive tissue and smooth muscle fibers' (second arrow). (b) Cancerous zone (prostate adenocarcinoma) $\times 40$. High staining $(+++)$ of smooth muscle fibers (second arrow) in the prostatic stroma. High staining $(+++)$ of cytoplasmic membrane (first arrow) of tiny and irregular cancerous glands, none festooned.

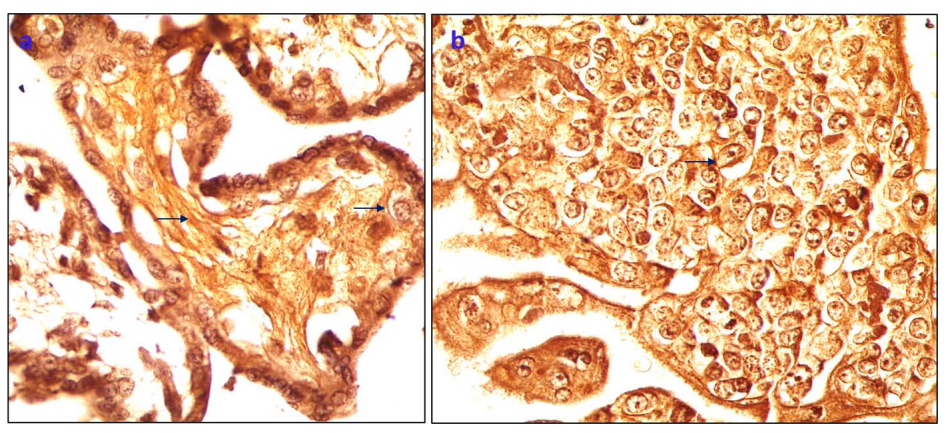

Figure 4. IHC Alpha tocopherol and choriocarcinoma. (a) Normal chorionic placental villous $\times 40$. Moderate $(++)$ staining of cytoplasmic membrane cells (second arrow) in STB, CTB, vascular endothelium, conjunctive tissue and in collagen fibers (first arrow). (b) Choriocarcinoma $\times 40$. strong $(+++)$ antibody reactivity in all villous trophoblast cells (arrow). 


\section{Discussion}

\subsection{Control Tissues}

Immunostaining in all internal control tissues (healthy section of tissue) was moderate (Figure 2(a), Figure 3(a) and Figure 4(a)). The normal tissue analysis had a double interest: it specified normal labelling and natural sites of $\alpha$-T. The results showed with evidence two localizations: 1) cellular membrane reactivity of epithelial cells (as ST, CTB, acini of lobes) and of conjunctive tissue cells (including fibroblast, adipocytes and endothelial). This localization reminds one of its important roles: protection of cell membranes that needs interaction with vitamin C, and which is transferred unpaired electron [18] [19]. It is known that $\alpha$-T is also present in intracellular organelle membranes as lysosome, endoplasmic reticulum and Golgi complex [5] [19]; 2) extracellular labelling is the second most location, especially in matrix extracellular fibers such as collagen (known to be secreted by fibroblast), in smooth muscle fibers in which the antibody exhibited also a strong staining. The staining in fibers suggests it role in collagen biosynthesis. Coveñas et al. [20] in their study have reported the fiber location, but they signalled that it not only available for vitamin E.

\subsection{Breast Cancer}

Regarding results (Figure 2(b), Figure 2(c)), no deficit was also observed in breast cancer tissues. $\alpha$-T was strongly expressed in cytoplasmic membrane cancerous cells, in stromal adipocytes and in fibers of tumor tissues compared to healthy section of tissue.

The breast is rich in adipose tissue where vitamin $\mathrm{E}$ is stocked with slow elimination. Currently, it is known that adipocytes of breast can stimulate breast cancer cells to acquire aggressive tumor phenotype [21]. These data raise the question of the used of adjuvant vitamin $\mathrm{E}$ therapy in breast cancer.

Literature review [6] [16] indicates that vitamin $\mathrm{E}$ is used for two reasons: Firstly, it considers as potential anticancer agent able to reduce cellular proliferation, angiogenesis, epigenetics events and progression of cancer metastasis. Secondly, it is indexed as antitoxicity agent in way to increase tolerance of treatment. The antioxidant propriety confers the potential to reduce oxidative damage in DNA cancer cells, genome instability, lipid and protein caused by chemotherapy and radiotherapy. It increases apoptosis, inhibits cell proliferation and decreases reactive oxygen species (ROS) or nitrogen species (RNS) activities in organism [1] [3] [18] [22]. The latter contains free radicals $R^{\star}$, superoxide anions $\left(\mathrm{O}_{2}^{-}\right)$, hydroxyle radical $(\mathrm{OH})$, alkoxyl radical $(\mathrm{RO})$, peroxyl radical $(\mathrm{ROO})$ that are very reactive molecules able to alter cells organism, to modify the stability of the genome and to make cancer nest [9] [10] [18].

The antioxidant or anti-free radicals principle is based on the power of $\alpha$-T to interrupt the autocatalytic chain $\left(\mathrm{R}^{\star}\right)$ by the transfer of the single electron from phenol to free radicals $\mathrm{R}^{\star}$ which become stable molecules and non toxic for the cells (Figure 1) [9] [19]. 
Currently, conflicting results are reported by some published study [3] [16] [22] [23]. Antioxidant supplement such as vitamin E, C or carotenoids $(\alpha, \beta$ and $\gamma$-carotene) used in the first months after breast cancer diagnosis may reduce risk of death and recurrence [23]. But, for some authors, antioxidant supplements seem to have also appearance adverse effects among patients with cancer. They seem to reduce radiotherapy efficacy [16]. Carcinogenic effects are observed by some authors with increased recurrence prostate cancer, cardiovascular disease, diabetes and colorectal adenoma among smokers and alcohol drinkers [16].

Amanda $\mathrm{K}$ et al. [7], reported in their study concerning all tocopherol forms supplementation, no protective benefits on breast cancer Erbb2/neu positif nice.

Another study had noticed that addition factor risks as tobacco and alcohol are harmful because they expose to cancer [18]. They highly decreased circulating $\alpha$-T level at $0.5 \mathrm{mg} / \mathrm{dl}$ compared to control group ( $0.94 \mathrm{mg} / \mathrm{dl})$. But, no deep $\alpha$-T deficiency $(0.77 \mathrm{~mm} / \mathrm{dl})$ was observed with breast cancer patients without those risk factors compared to group control. Moreover, Hu F et al. [24], concluded in his meta-analysis work, that severe $\alpha$-T deficiency could increase breast cancer.

\subsection{Prostate Cancer}

The cancerous tissues sections exhibited a high staining, more pronounced in smooth muscle fibers in the prostatic stroma (Figure 3(b)). Note that, stroma plays a crucial role in cancer progression and in cell proliferation at metastatic sites [25]. The expression of $\alpha$-T in the proliferative cancerous prostatic cells is not in accordance with another biological role of $\alpha$-T that of being inducer of apoptosis and inhibitor of cell proliferation. But, in some circumstances, $\alpha$-T could have a co-carcinogenic effect. That suggestion is reinforced by Amanda et al. [7] study, in which, only $\alpha$-tocopherol didn't induce apoptosis and inhibition of cell proliferation in breast cancer estrogen receptor positif. In another published work, the authors had also evocated the possibility that vitamin E (especially $\alpha$-T) may have alternative functions [3] [9].

Indeed, Heinonen et al., [26], using clinical trials study $\alpha$-T $(50 \mathrm{mg} /$ day), $\beta$-carotene $(20 \mathrm{mg} /$ day) supplementation (ATBC), reported a reduced incidence of prostate cancer and lower mortality among men smokers. In another ATBC study, the authors observed among smoker patients, beneficial effects of high serum level of $\alpha$-T associated with reduced risk of prostate cancer especially advanced cancer [27].

In opposite, some research studies showed that vitamin $\mathrm{E}(\alpha-\mathrm{T})$ supplementation increases (in epithelial and stromal cells) expression of genes with multiple network connections (as TP53, ST14, TOP1, HRAS, ERCC3, SLC2A3, CREB1, $C Y P$ ) [14] [15] [25]. Those genes promote the cell proliferation and cell survival which predispose to prostate cancer development [14] [15] [25]. In addition, vitamin E increases sex hormones and it is not quickly degraded and excreted [8] [28]. 
On a final note, one study indicates that, $\gamma$-T and $\delta$-T (compare to $\alpha$-T) have mayor anti-inflammatory and anticancer properties to prevent early stage of prostate cancer than $\alpha$-T [6]. $\alpha$-T and $\gamma$-T levels are significantly associated. Unfortunately, high level of $\alpha$-T decreases $\gamma$-T level [9] [28].

\subsection{Choriocarcinoma}

The analysis showed that choriocarcinoma tissues were enriched in $\alpha$-T like the precedent cancerous tissues (Figure $4(\mathrm{~b})$ ). The choriocarcinoma staining suggests also the absence of inhibitor role of $\alpha$-T in cancerous CTB cells proliferation.

Aris et al., [29], in their study had reported that exposure of CTB to high level $\alpha$-T may affect placental function. In another published study on the human choriocarcinoma cell line BeWo, it is reported that $\alpha$-tocopherol transfer protein (a major intracellular transport protein for $\alpha$-T) is over expressed, probably in response to the intensified oxidative stress caused by the cancerous cells [30].

The conflicting results about the effect of vitamin E supplementation in cancers and our results show again that vitamin $\mathrm{E}$ (especially $\alpha$-T) biological process is not still entirely understood. We have in Table 2, done a comparison with other countries [5] [20] [31] [32]. Our results are consistent with some review data.

Therefore, all these data (review and our findings) make things difficult for vitamin $\mathrm{E}$ instructions especially to patients with cancers. However, Guidelines for cancer survivors recommends among other things: no intake of supplements in preventing recurrence [33]. It promotes the lifestyle change (physical exercise, no smoking and no alcohol drinking) and to have a vitamin E-rich eating pattern [34]. But, it must it be in the short-term, especially for elderly people, because of the probable increased $\alpha$-T plasma level with aging [31].

Table 2. Alpha-tocopherol results compared with review data.

\begin{tabular}{|c|c|c|c|c|}
\hline Countries & Soft tissues & Breast cancer & Prostate cancer & References \\
\hline Congo & $\begin{array}{l}\text { Moderate labelling of: } \\
\text { epithelial membrane cells, } \\
\text { fibers, conjunctive tissue } \\
\text { cells and adipocyte tissue }\end{array}$ & $\begin{array}{l}\text { High labeling } \\
\text { of cytoplasmic } \\
\text { membranes } \\
\text { and fibers }\end{array}$ & $\begin{array}{l}\text { High staining of fibers, } \\
\text { cytoplasmic and nuclear } \\
\text { membranes in } \\
\text { cancerous cells }\end{array}$ & $\begin{array}{l}\text { Present } \\
\text { study }\end{array}$ \\
\hline Spain & $\alpha-\mathrm{T}$ staining of fibers & NM & NM & {$[20]$} \\
\hline Germany & $\begin{array}{l}\text { Present in stromal cells } \\
\text { (fibroblasts), lysosomes }\end{array}$ & NM & NM & {$[31]$} \\
\hline Japan & $\begin{array}{c}\text { a-T labelling of } \\
\text { membranes of } \\
\text { intracellular organelles } \\
\text { (ER, GC, mitochondria) }\end{array}$ & NM & NM & {$[5]$} \\
\hline China & NM & $\begin{array}{c}\text { Proliferation of } \\
\text { cancer cells with } \\
\text { cytoplasmic } \\
\text { membrane staining }\end{array}$ & NM & {$[32]$} \\
\hline
\end{tabular}

Abbreviations: ER, endoplasmic reticulum; GC, golgi complex; NM, not mentioned; $\alpha$-T, alpha-tocopherol. 


\section{Conclusion}

$\alpha$-tocopherol is a positive biomarker for cellular membranous and fibers in the breast and prostate cancers and choriocarcinoma tissues. Findings from our work suggest that systematic vitamin E supplementation containing high dose of $\alpha$-T may have harmful effects in those cancerous tissues. For this reason, specification of vitamin $\mathrm{E}$ form, plasma concentration, duration of intake and type of cancer must be determined before vitamin E administration. Great cohorts' study on each natural form $\alpha, \beta, \gamma$ and $\delta$-tocopherol should be analysed in way to confirm our preliminaries results.

\section{Acknowledgements}

The work was supported in part by GEMAC SA, IRSSA Institute and PCD Association. We are grateful to Pr Benjamin Evayoulou for the English proofreading.

\section{Conflicts of Interest}

We declare no competing interest exists for any of the authors.

\section{Author's Contributions}

Conceived, designed the experiments and wrote the paper: HP. Performed the experiments and analyzed the data: FAMK, HP. Contributed reagents, materials and tools: MG, AFBL and JSM.

\section{References}

[1] Poljsak, B. and Milisav, I. (2018) The Role of Antioxydant in Cancer, Friends or Foes? Current Pharmaceutical Design, 24, 5234-5244. https://doi.org/10.2174/1381612825666190123112647

[2] Greenlee, H., Kwan, M.L., Ergas, I.J., et al. (2014) Changes in Vitamin and Mineral Supplement Use after Breast Cancer Diagnosis in the Pathways Study: A Prospective Cohort Study. BMC Cancer, 14, Article No. 382. https://doi.org/10.1186/1471-2407-14-382

[3] Brigelius-Flohé, R., Kelly, F.J., Salonen, J.T., et al. (2002) The European Perspective on Vitamin E: Current Knowledge and Future Research. The American Journal of Clinical Nutrition, 76, 703-716. https://doi.org/10.1093/ajcn/76.4.703

[4] Herrera, E. and Barbas, C.J. (2001) Vitamin E: Action, Metabolism and Perspectives. Journal of Physiology and Biochemistry, 57, 43-56. https://doi.org/10.1007/BF03179812

[5] Arita, M., Sato, Y., Miyata, A., et al. (1995) Human $\alpha$-Tocopherol Transfer Protein: cDNA Cloning, Expression and Chromosomal Localization. Biochemical Journal, 306, 437-443. https://doi.org/10.1042/bj3060437

[6] Jiang, Q. (2017) Natural Forms of Vitamin E as Effective Agents for Cancer Prevention and Therapy. Advances in Nutrition, 8, 850-867. https://doi.org/10.3945/an.117.016329

[7] Smolarek, A.K., So, J.Y., Burgess, B., Kong, A.-N.T., et al. (2012) Dietary Administration of $\delta$ and $\gamma$ Tocopherol Inhibits Tumorigenesis in the Animal Model of Estrogen Receptor-Positive, but Not HER-2 Breast Cancer. Cancer Prevention Re- 
search, 5, 1310-1320. https://doi.org/10.1158/1940-6207.CAPR-12-0263

[8] Hu, X.-X., Fu, L., Li, Y., et al. (2015) The Cardioprotective Effect of Vitamin E (Alpha-Tocopherol) Is Strongly Related to Age and Gender in Mice. PLoS ONE, 10, e0137405. https://doi.org/10.1371/journal.pone.0137405

[9] Smolarek, A.K. and Suh, N. (2011) Chemopreventive Activity of Vitamin E in Breast Cancer: A Focus on $\gamma$ - and $\delta$-Tocopherol. Nutrients, 3, 962-986. https://doi.org/10.3390/nu3110962

[10] Erbas, H., Türksever, A., Aydogdu, N., et al. (2015) Asymmetric Dimethylarginine in Experimental Breast Cancer; Action of Vitamin C and E. Journal of Pakistan Medical Association, 65, 829-833.

[11] Sondé Malanda, J., Nkoua Mbon, J.B., Tozoula Bambara, A., et al. (2013) Twelve Years of Working of Brazzaville Cancer Registry. Bulletin du Cancer, 100, 135-139. https://doi.org/10.1684/bdc.2013.1701

[12] Barta, J.A., Powell, C.A. and Wisnivesky, J.P. (2019) Global Epidemiology of Lung Cancer. Annals of Global Health, 85, 8. https://doi.org/10.5334/aogh.2419

[13] Bashir, M.N. (2015) Epidemiology of Prostate Cancer. Asian Pacific Journal of Cancer Prevention, 16, 5137-5141. https://doi.org/10.7314/APJCP.2015.16.13.5137

[14] Vivarelli, F., Canistro, D., Cirillo, S., et al. (2019) Co-Carcinogenic Effects of Vitamin E in Prostate. Scientific Reports, 9, Article No. 11636.

https://doi.org/10.1038/s41598-019-48213-1

[15] Njoroge, R.N., Unno, K., Zhao, J.C., et al. (2017) Organoids Model Distinct Vitamin E Effects at Different Stages of Prostate Cancer Evolution. Scientific Reports, 7, Article No. 16285. https://doi.org/10.1038/s41598-017-16459-2

[16] Harvie, M. (2014) Nutrtional Supplements and Cancer: Potential Benefits and Proven Harms. American Society of Clinical Oncology Educational Book, 34, e478-e486. https://doi.org/10.14694/EdBook_AM.2014.34.e478

[17] Poaty, H., Aba Gandzion, C., Soubeyran, I., et al. (2017) The Identification of Lynch Syndrome in Congolese Colorectal Cancer Patients. Bulletin du Cancer, 104, 831-839. https://doi.org/10.1016/j.bulcan.2017.08.005

[18] Nagamma, T., Baxi, J. and Singh, P.P. (2014) Status of Oxidative Stress and Antioxidant Levels in Smokers with Breast Cancer from Wester Nepal. Asian Pacific Journal of Cancer Prevention, 15, 9467-9470.

https://doi.org/10.7314/APJCP.2014.15.21.9467

[19] Wang, X. and Quinn, P.J. (1999) Vitamin E and Its Function in Membranes. Progress in Lipid Research, 38, 309-336.

https://doi.org/10.1016/S0163-7827(99)00008-9

[20] Covenas, R., Mangas, A., Bodet, D., et al. (2011) Frontiers in Vitamin Research: New Antibodies, New Data. The Scientific World Journal, 11, Article ID: 586180. https://doi.org/10.1100/tsw.2011.115

[21] Lee, Y.K., Jung, W.H. and Koo, J.S. (2015) Adipocytes Can Induce Epithelial-Mesenchymal Transition in Breast Cancer Cells. Breast Cancer Research and Treatment, 153, 323-335. https://doi.org/10.1007/s10549-015-3550-9

[22] Ramamoorthy, V., Rubens, M., Saxena, A. and Shehadeh, N. (2015) Selenium and Vitamin E for Prostate Cancer-Justifications for the SELECT Study. Asian Pacific Journal of Cancer Prevention, 16, 2619-2627. https://doi.org/10.7314/APJCP.2015.16.7.2619

[23] Nechuta, S., Lu, W., Chen, Z., et al. (2011) Vitamin Supplement Use during Breast Cancer Treatment and Survival: A Prospective Cohort Study. Cancer Epidemiology, 
Biomarkers \& Prevention, 20, 262-271. https://doi.org/10.1158/1055-9965.EPI-10-1072

[24] Hu, F., Wu, Z., Li, G., et al. (2015) The Plasma Level of Retinol, Vitamins A, C and $\alpha$-Tocopherol Could Reduce Breast Cancer Risk? A Meta-Analysis and Meta-Regression. Journal of Cancer Research and Clinical Oncology, 141, 601-614. https://doi.org/10.1007/s00432-014-1852-7

[25] Tsavachidou, D., McDonnell, T.J., Wen, S., et al. (2008) Selenium and Vitamin E: Cell Type- and Intervention-Specific Tissue Effects in Prostate Cancer. Journal of the National Cancer Institute, 101, 306-320. https://doi.org/10.1093/jnci/djn512

[26] Heinonen, O.P., Albanes, D., Virtamo, J., et al. (1998) Prostate Cancer and Supplementation with Alpha-Tocopherol and Beta-Carotene: Incidence and Mortality in Controlled Trial. Journal of the National Cancer Institute, 90, 440-446.

https://doi.org/10.1093/jnci/90.6.440

[27] Weinstein, S.J., Wright, M.E., Lawson, K.A., et al. (2007) Serum and Dietary Vitamin E in Relation to Prostate Cancer Risk. Cancer Epidemiology, Biomarkers \& Prevention, 16, 1253-1259. https://doi.org/10.1158/1055-9965.EPI-06-1084

[28] Waniek, S., Di Giuseppe, R., et al. (2018) Vitamin E ( $\alpha$ - and $\gamma$-Tocopherol) Levels in the Community: Distribution, Clinical and Biochemical Correlates, and Association with Dietary Patterns. Nutrients, 10, 3. https://doi.org/10.3390/nu10010003

[29] Aris, A., Leblanc, S., Ouellet, A. and Moutquin, J.-M. (2008) Detrimental Effect of High Levels of Antioxidant Vitamins $\mathrm{C}$ and $\mathrm{E}$ on Placental Function: Consideration for the Vitamins in Preeclampsia (VIP) Trial. Journal of Obstetrics and Gynaecology Research, 34, 504-511. https://doi.org/10.1111/j.1447-0756.2008.00722.x

[30] Etzl, R.P., Vrekoussis, T., Kuhn, C., et al. (2012) Oxidative Stress Stimulates Alpha-Tocophérol Transfer Protein in Human Trophoblast Tumor Cells BeWo. Journal of Perinatal Medicine, 40, 373-378. https://doi.org/10.1515/jpm-2011-0307

[31] Konig, J., Besoke, F., Stuetz, W., et al. (2016) Quantification of Age-Related Changes of $\alpha$-Tocopherol in Lysosomal Membranes in Murine Tissues and Human Fibroblasts. Biofactors, 42, 307-315.

[32] Diao, Q.X., Zhang, J.Z., Zhao, T., et al. (2016) Vitamin E Promotes Breast Cancer Cell Proliferation by Reducing ROS Production and p53 Expression. European Review for Medical and Pharmacological Sciences, 20, 2710-2717.

[33] Rock, C.L., Doyle, C., Demark-Wahnefried, W., et al. (2012) Nutrition and Physical Activity Guidelines for Cancer Survivors. CA: A Cancer Journal for Clinicians, 62, 242-274. https://doi.org/10.3322/caac.21142

[34] Ferrini, K., Ghelfi, F. and Mannucci, R. (2015) Lifestyle, Nutrition and Breast Cancer: Facts and Presumptions for Consideration. Ecancer Medical Science, 9, 557 https://doi.org/10.3332/ecancer.2015.557 